\title{
Morphological Variation of Fissure and Lobe of the Left Lung: A Case Report
}

\author{
Atoni Atoni Dogood ${ }^{1}$, Oyinbo Charles Aidemise ${ }^{1}$, Udoye Ezenwa Patrick ${ }^{2}$ \\ ${ }^{1}$ Department of Anatomy, Faculty of Basic Medical Sciences, Niger Delta University, Wilberforce Island, Bayelsa State, \\ Nigeria \\ ${ }^{2}$ Department of Anatomical Pathology, Faculty of Basic Medical Sciences, Niger Delta University, Wilberforce Island, \\ Bayelsa State, Nigeria
}

\section{SUMMARY}

The left lung usually has an oblique fissure that divides it into superior and inferior lobes. Some variants in the lobar fissure are well known, but the knowledge of certain uncommon variants will enhance our anatomical understanding and proper identification of the bronchopulmonary segments. Several imaging techniques have been used to describe anatomical variations of the lung, but studies that utilize dissections as tools for understanding lobar variations were limited. In this report, we described an incomplete horizontal fissure, bifurcated accessory fissure, incomplete superior and middle lobes, and fibrous condensation of the left lung pulmonary pleura observed during dissection. The knowledge of these anatomical variations will be useful in surgical segmental resection and lobectomy, and for accurate interpretations of medical diagnostic images.

Key words: fissure, lobes, pulmonary pleura, lobectomy 


\section{INTRODUCTION}

The oblique and horizontal fissures divide the lungs into lobes. The right lung is divided into three lobes-upper, middle and lower by the oblique and horizontal fissures. The left lung has only an oblique fissure and hence only two lobes. At the level of the $3^{\text {rd }}$ and $4^{\text {th }}$ thoracic vertebrae, the oblique fissure incises the posterior border of both left and right lungs. It then passes downwards to terminate above the hilum on the mediastinal surface, and passes downwards on the costal surface, runs across the diaphragmatic surface and turns upward to terminate just below the lower end of the hilum on the mediastinal surface (1). The left lung is divided into superior and inferior lobes by the oblique fissure $(1,2)$.

On the costal surface of the right lung, the horizontal fissure starts its journey from the oblique fissure, and running almost transversely, incises the anterior margin and curves backwards to terminate at the hilum on the mediastinal surface (1). Complete fissures separate the lungs into complete lobes, which is characterized by holding together of the lobes by the bronchi and pulmonary vessels only at the hilum. However, the fusion of parenchyma between the lobes may result in incomplete fissures, which may also separate the lungs into incomplete lobes, or sometimes a complete absence of fissures (3). These fissures cause significant uniform expansion of the whole lung by facilitating lobar movements in relation to one another which culminate in significant inferior lobes expansion during respiration $(1,6)$.

Proper knowledge of fissure and lobe variability is important to both anatomists and clinicians in locating bronchopulmonary segments. Hence, the knowledge of these variations may aid correct segmental resections and pulmonary lobectomies in surgery. It will also help in the interpretation of medical diagnostic images.

\section{CASE REPORT}

In the gross laboratory of Anatomy Department, the left lung of a 40-year-old male cadaver presented a horizontal fissure, middle lobe, and two accessory fissures on the costal and mediastinal surfaces, respectively, during routine dissection of the thorax. The fissures and lobes were studied and snapshots of the costal surface and the mediastinal surface were taken (Figure 1 and Figure 2). It also presented incomplete horizontal fissure that passed transversely from the oblique fissure across the costal surface and disappeared at the anterior border.

The incomplete horizontal fissure on the costal surface divided the lung into incomplete superior and inferior lobes, respectively. The oblique fissure maintained its normal course across the mediastinal, costal and diaphragmatic surfaces, respectively, as described.

On the superior lobe of the costal surface, an accessory fissure started a short upward journey from the horizontal fissure above a fibrous condensation of pulmonary pleura with a brief bifurcation dividing the superior lobe into partial lobes. Another accessory fissure (left minor fissure) was also observed within the upper lobe, it ran downwards and forwards from the front of the hilum on the mediastinal surface to terminate at the anterior margin above the lingula.

The left lung also presented a fibrous condensation of pulmonary pleura extending into the lung between the horizontal fissure and the accessory fissure. The cut end of the fibrous condensation of pulmonary pleura was initially attached to the costal pleura. Pathological examination identified this fibrous condensation as a fibrous pleural adhesion over a subpleural bleb (red arrow, Figure 1). Histopathological examination of the condensed

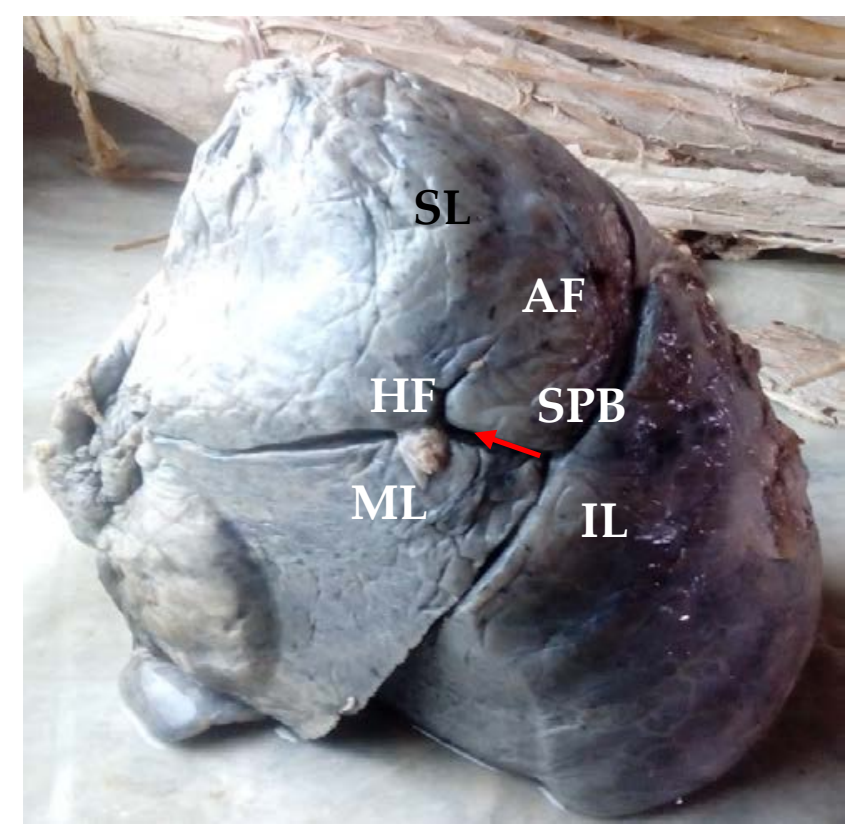

Figure 1. Costal surface showing SL- superior lobe; ML- middle lobe; IL- inferior lobe; AF- accessory fissure; SPB- subpleural bleb (red arrow); OBoblique fissure 


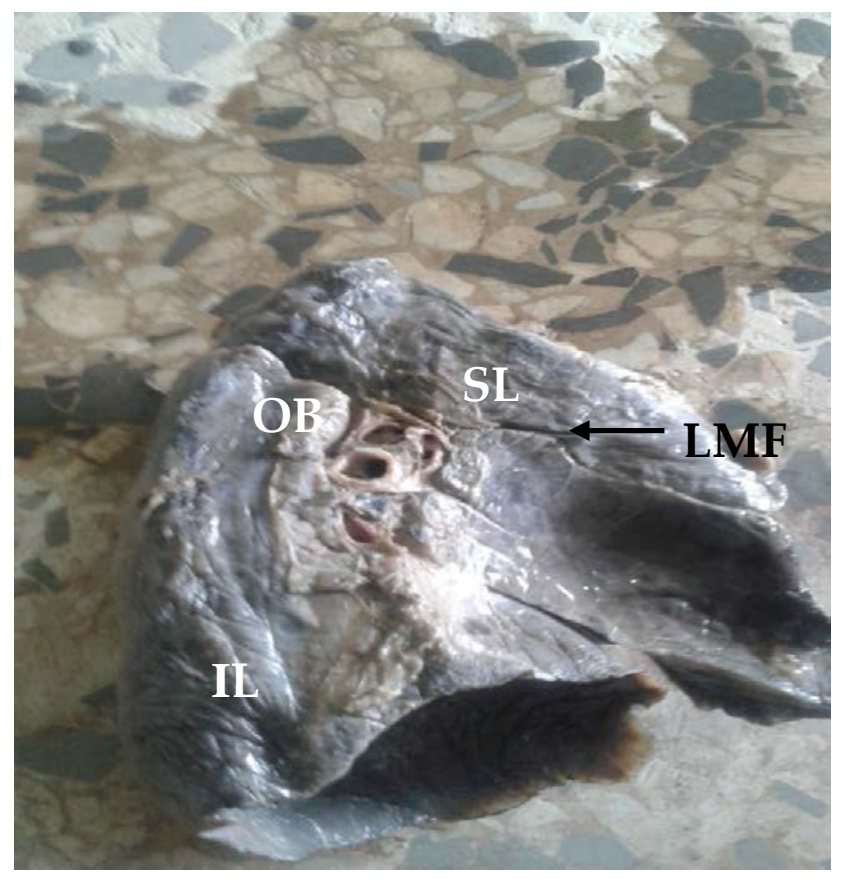

Figure 2. Mediastinal surface showing (LMF- left minor fissure; OB- oblique fissure; SL- superior lobe; IL- inferior lobe.

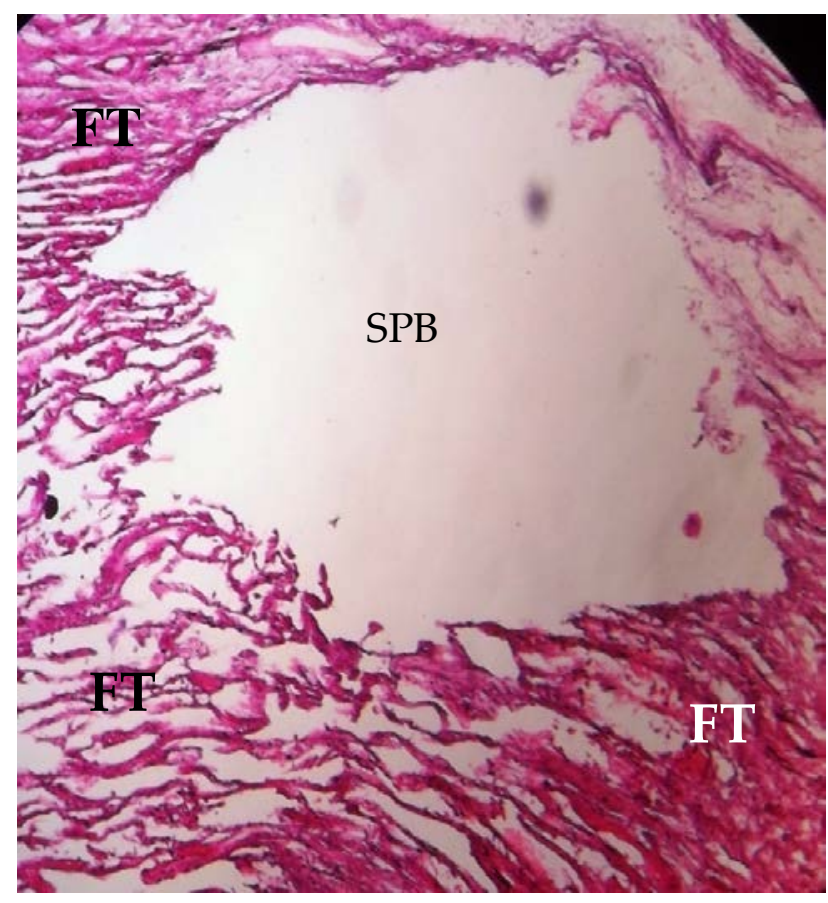

Figure 3. Section of fibrous condensation (H\&E X400) FT- fibrous tissue, SPB- subpleural bleb

Section of the tissue shows fibrous pleural adhesions over a small subpleural bleb.

fibrous tissue using routine haematoxylin and eosin staining technique shows fibrous pleural adhesions over a small area of subpleural bleb (Figure 3).

\section{DISCUSSION}

The oblique fissure and horizontal fissure are two exceptional embryonic planes which remained nonobliterated as seen in completely developed lungs, however, most of the spaces separating bronchopulmonary segments/buds in lungs during development become obliterated. The partial obliteration of oblique fissure or horizontal fissure results in incomplete fissures, while complete obliteration of oblique fissure or horizontal fissure results in the absence of these fissures. The nonobliterated embryonic lung spaces which would have been obliterated become accessory fissure in a completely developed lung (4). Lobar and fissure variability may be caused by abnormal lung development (5).

Pulmonary pleura extend into lung fissures to allow free movement of lobes during respiration. These fissures may be obliterated by pleurisy and abscess may be formed between the lobes of the lungs due to localized infection in the fissure (6).

The presence of fissures in the normal lungs enhances uniform expansion, and their positions could be used as reliable landmarks in specifying legions within the thorax in general and within the lungs in particular (7). Incomplete pulmonary fissures indicating partial parenchymal fusion between lobes accounts for more than half of the incomplete pulmonary fissures (3). Interestingly, there has been no report on the left lung incomplete horizontal fissure and the bifurcated accessory fissure reported in this study.

Occasionally, especially in the infant, varying depth of accessory fissures may be observed in odd pulmonary locations, thereby increasing anomalous lobes that correspond to the normal bronchopulmonary segments (11). Radiologically, an accessory fissure may be misinterpreted to be a lung lesion (8). The present report showed an incomplete horizontal fissure, a bifurcated accessory fissure and a left minor fissure.

Abnormal radiographic image of pleural effusion may be due to an anomalous fissure. The challenge of identifying accessory fissure most times is due to their truncated course, dense sections and orientation in relation to a particular plane (9). Anomalous fissure sometimes is the cause of air leakage after lung surgery (10). However, accessory fissures act as barriers to the spread of pneumonia, inflammation and neoplastic disease which may be wrongly interpreted as legions (11). 
Diseases such as pneumonia and cancer are often limited only to the particular infected lobe by fissures. Incomplete fissures serve as pathways for the spread of the above mentioned diseases to adjacent lobes. Preoperative planning and strategy for segmental resection and pulmonary lobectomy may also change when accessory or unusual fissure is present (12). Detailed awareness of the anatomy of fissures may give better understanding of difficult radiographic evidence such as the flow of fluid into an incomplete major fissure or spread of various diseases via different channels (13).

Due to the clinical and surgical relevance of variations of the pattern of fissures and lobes, detailed knowledge of anatomical lung variations may be helpful in diagnosis and treatment of diseases.
The fibrous pleural adhesion over a small subpleural bleb mentioned in this report is not an unusual finding and does not represent pathology. Extensive pleural adhesions may result from a recurrent lung inflammation, such as pneumonia, and can trap leaking air from a bleb as in this case. Pulmonary blebs are not visible on chest $x$-rays, but can be seen in the lung windows of CTs, a fact useful in medical diagnostic imaging. However, in the vast majority of cases, blebs remain asymptomatic and are often found in young patients, with a predilection for thin patients, and cigarette smokers (14).

The knowledge of the variations reported here will aid accurate interpretations of medical diagnostic images.

\section{References}

1. Chummy SS. Last's Anatomy. Regional and Applied. 12th Ed., London, Churchill Livingstone. 2011; p 207-8.

2. Standring S, Borley NR, Collins $\mathrm{P}$ et al .Gray's Anatyomy:The Anatomical Basis of Clinical Practice-. Gray's Anatomy. New York: Churchill pleura, lungs, trachea and bronchi. 40th Ed., Spain, Churchill Livingstone 2008: 993-5.

3. Meenakshi S, Manjunath KY, BalasubramanYam V. Morphological variations of lung fissures and lobes. Indian J chest Dis Allied Sci. 2004; 46: 179-82.

4. Herriges M, Morrisey EE. Lung development: orchestrating the generation and regeneration of a complex organ. Development. 2014; 141:502-13.

https://doi.org/10.1242/dev.098186
5. Joshi S, Kotecha S. Lung growth and development. Early Human Development, 2007; 83:789-94.

https://doi.org/10.1016/j.earlhumdev.2007.09.007

6. Romanes GJ. Cunningham's manual of practical anatomy. Thorax and abdomen vol.2 15th Ed. New York, Oxford University Press. 2012; p 32-3.

7. Wei Q, Hu Y, Macgregor JH, Gelfand G. Identification of lobar fissures in pathological lungs. Conf Proc IEEE Eng Med Biol Soc. 2010; 2010:5347-50. https://doi.org/10.1109/iembs.2010.5626469

8. Ozmen CA, Nazaroglu H, BaryakAH et al. Evaluation of interlobar and accessory pulmonary fissures on 64-row MDCT. Clin Anat 2010; 23:552-558. https://doi.org/10.1002/ca.20971 
9. Ariyurek OM, Gulsun M, Demirkazik FB. Accessory fissures of the lung: evaluation by high resolution computed tomography. Eur Radiol 2001; 11: 2449-53. https://doi.org/10.1007/s003300100852

10. Taverne Y, KleinrensinkGJ, de Rooij P. Perioperative Identification of an accessory fissure of the right lung. Case Report in Pulmon 2015; 2015:954769 https://doi.org/10.1155/2015/954769

11. Jose T, Muttikal E, Deng C. Non-azygos accessory fissure in right upper lobe associated with superior and inferior accessory fissures in right lower lobe. J Clin
Imaging Sci., 2012; 2:79.

https://doi.org/10.4103/2156-7514.105133

12. Nene AR, Gajndra KS, Sarma MVR. Lung lobes and fissures: a morphological study. Anatomy, 2011; 5: 30-8.

https://doi.org/10.2399/ana.10.005

13. Prakash, Bharadwaj AM, Shashirekha M, Suma HY, Krishna GG, Singh G. Lung morphology: a cadaver study in Indian population. Ital J Anat Embryol, 2010; 115:235-40.

14. Shields TW. General Thoracic Surgery. Wolter Kluwer/Lippincott Williams \& Wilkins.(2009). 


\title{
Morfološka varijacija fisure i režnja levog plućnog krila: prikaz slučaja
}

\author{
Atoni Atoni Dogood ${ }^{1}$, Oyinbo Charles Aidemise ${ }^{1}$, Udoye Ezenwa Patrick ${ }^{2}$ \\ ${ }^{1}$ Departman za anatomiju, Fakultet za osnovne medicinske nauke, Univerzitet Niger Delta, \\ Wilberforce, Savezna država Bayelsa, Nigerija \\ ${ }^{2}$ Departman za anatomsku patologiju, Fakultet za osnovne medicinske nauke, Univerzitet Niger \\ Delta, Wilberforce, Savezna država Bayelsa, Nigerija
}

\section{SAŽETAK}

U levom plućnom krilu se obično nalazi kosa fisura koja ga deli na gornji i donji režanj. Pojedine varijante lobarnih fisura su već poznate, što samo nadgrađuje naše poznavanje anatomije i utiče na pravilnu identifikaciju bronhopulmonalnih segmenata. Do sada je za opisivanje anatomskih varijacija pluća primenjeno nekoliko radioloških metoda, dok je broj studija u kojima je primenjivana disekcija kako bi se bolje razumele lobarne varijacije ograničen. $U$ ovom prikazu slučaja opisali smo nekompletnu horizontalnu fisuru, granatu aksesornu fisuru, nekompletni gornji i srednji režanj, kao i fibroznu kondenzaciju pleure levog plućnog krila uočenu u toku disekcije. Poznavanje ovih anatomskih varijacija će biti od koristi kod hirurških segmentnih resekcija i lobektomija, kao i za tačnu interpretaciju medicinskih dijagnostičkih tehnika.

Ključne reči: fisura, režnjevi, plućna maramica, lobektomija 